\title{
PENINGKATAN HASIL BELAJAR MELALUI STRATEGI PEMBELAJARAN LANGSUNG (DIRECT INSTRUCTION) MATA PELAJARAN BAHASA INDONESIA SDN 167644 KOTA TEBING TINGGI
}

\author{
Rohani \\ Guru SD Negeri 167644 Kota Tebing Tinggi \\ Surel : Rohani04@gmail.com
}

\begin{abstract}
This aim of this research is to know improvment of learning result on Indonesian language subject through direct instruction strategy. This classroom action research conducted by 2 cycles of the four phases: planning, implementation, observation, reflection. The subjects were students from class I, SDN 167644 Tebing Tinggi which amounted to 33 students. This study used a qualitative descriptive analysis technique. The results showed that the use of direct instruction strategy of Indonesian language subjects can improve student learning result characterized by increased mastery learning students, namely precycle $(69,69 \%)$, the first cycle $(78,78 \%)$, cycle II $(90,90 \%)$ and complete learn the clasical equal to $90,90 \%$.
\end{abstract}

Key word : direct instruction, language, learning result

\section{PENDAHULUAN}

Kualitas pembelajaran dapat dilihat dari segi proses dan hasil pembelajaran. Dari segi proses pembelajaran dikatakan berhasil apabila seluruhnya atau setidak-tidaknya sebagian besar $(75 \%)$ peserta didik terlibat secara aktif, baik fisik, mental maupun sosial dalam proses pembelajaran disamping menunjukkan kegairahan belajar tinggi, semangat belajar besar dan rasa percaya diri yang tinggi. Bahasa Indonesia merupakan salah satu mata pelajaran yang diajarkan pada setiap jenjang pendidikan, mulai dari TK, SD, SMP, dan SMA sampai Perguruan Tinggi. Salah satu dasar pertimbangannya karena Bahasa Indonesia adalah suatu alat untuk mengembangkan cara berpikir yang mendasari perkembangan teknologi modern.

Pada dasarnya Bahasa Indonesia merupakan sebuah fakta sosial dan juga sarana komunikasi, sehingga dengan pendekatan pada pembelajaran Bahasa Indonesia yang dikembangkan harus selalu mengaitkan antara keduanya. Adapun keterampilan Berbahasa Indonesia meliputi: 1) mendengarkan, 2) berbicara, 3) membaca dan 4) menulis (Krisnawati, dkk., 2013).

Sebuah proses pembelajaran mutlak diperlukan adanya sebuah strategi pembelajaran. Hal ini dimaksudkan agar pembelajaran tidak berlangsung seadanya. Pembelajaran haruslah berlangsung dengan terencana. Dampak intruksional dan dampak pengiringnya harus sudah dapat terproyeksikan sebelumnya. Pembelajaran membaca dan menulis di kelas I merupakan pembelajaran tahap awal. Dengan membaca dan menulis siswa akan mengenali huruf-huruf dan membacanya sebagai suku kata, kata dan kalimat sederhana.

Berdasarkan hasil observasi dari peneliti, hasil belajar siswa kelas I SD Negeri 167644 belum mencapai Kriteria 
Ketuntasan Minimal yanga di tetapkan yaitu sebesar 65 dan indikator keberhasilan $85 \%$ jumlah siswa mencapai KKM. Nilai rata-rata yang dicapai siswa hanya mencapai 57,50.

Hal ini dapat dilihat dari hasil belajar siswa. Dari 33 siswa kelas I SD Negeri 167644 hanya 23 siswa yang lulus secara klasikal. Setelah peneliti mencermati ternyata siswa kurang tertarik dan kurang aktif dalam mengikuti pembelajaran. Hal ini disebabkan oleh guru yang dalam pembelajaran sering menggunakan metode ceramah dan mengerjakan tugas, dan belum menggunakan metode pembelajaran yang efektif, sehingga siswa mendapat pemahaman yang masih abstrak.

Salah satu upaya yang digunakan untuk mengatasi masalah tersebut adalah dengan menggunakan strategi direct instruction pada saat proses pembelajaran. Strategi pembelajaran langsung (direct instruction) merupakan sebuah model pembelajaran yang menitik beratkan pada penugasan konsep dan juga perubahan perilaku dengan melakukan pendekatan secara deduktif.

Model Pembelajaran Langsung (Direct Instruction) merupakan salah satu model pengajaran yang dirancang khusus untuk mengembangkan belajar siswa tentang pengetahuan prosedural dan pengetahuan deklaratif yang terstruktur dengan baik dan dapat dipelajari selangkah demi selangkah. Yang dimaksud dengan pengetahuan deklaratif (dapat diungkapkan dengan kata-kata) adalah pengetahuan tentang sesuatu. sedangkan pengetahuan prosedural adalah pengetahuan tentang bagaimana melakukan sesuatu (Amri \& Ahmadi, 2010:39).

Menurut Trianto (2009:41), pengajaran langsung adalah suatu model pengajaran yang bersifat teacher center. "model pengajaran langsung adalah salah satu pendekatan mengajar yang dirancang khusus untuk menunjang proses belajar siswa yang berkaitan dengan pengetahuan deklaratif dan pengetahuan procedural yang terstruktur dengan baik yang dapat diajarkan dengan pola kegiatan yang bertahap, selangkah demi selangkah.

Menurut Arends (1997), model pengajaran langsung adalah salah satu pendekatan mengajar yang dirancang khusus untuk menunjang proses belajar siswa yang berkaitan dengan pengetahuan deklaratif dan pengetahuan prosedural yang terstruktur dengan baik yang dapat diajarkan dengan pola kegiatan yang bertahap, selangkah demi selangkah. Selain itu model pembelajaran langsung ditujukan pula untuk membantu siswa mempelajari keterampilan dasar dan memperoleh informasi yang dapat diajarkan selangkah demi selangkah.

Metode pengajaran langsung ini dirancang khusus untuk menunjang proses belajar siswa yang berkaitan dengan pengetahuan prosedural dan pengetahuan deklaratif yang terstruktur dengan baik, yang dapat diajarkan dengan pola kegiatan yang bertahap, selangkah demi selangkah.

Suatu pelajaran dengan metode pengajaran langsung berjalan melalui lima fase, yaitu: (1) penjelasan tentang tujuan dan persiapan siswa; 
pemahaman/ presentasi materi ajar yang akan diajarkan atau demonstrasi tentang keterampilan tertentu; (3) memberikan latihan terbimbing; (4) mengecek pemahaman dan memberikan umpan balik; (5) memberikan latihan mandiri (Harjani, 2010 ).

Menurut Trianto (2007: 30-31), pada model Direct Instruction terdapat lima fase yang sangat penting, yaitu sebagai berikut :

\section{Tabel Fase-Fase Model Pembelajaran} Direct Instruction

\begin{tabular}{|l|l|}
\hline $\begin{array}{l}\text { Fase-fase Model } \\
\text { Pembelajaran } \\
\text { Firect Instruction }\end{array}$ & \multicolumn{1}{|c|}{ Peran Guru } \\
\hline $\begin{array}{l}\text { Fase 1 } \\
\text { Menyampaikan } \\
\text { tujuan dan } \\
\text { mempersiapkan } \\
\text { siswa }\end{array}$ & $\begin{array}{l}\text { Geru menjelaskan } \\
\text { belakang pelajaran, } \\
\text { pentingnya pelajaran, } \\
\text { mempersiapkan siswa } \\
\text { untuk belajar }\end{array}$ \\
\hline $\begin{array}{l}\text { Fase 2 } \\
\text { Mendemonstrasika } \\
\text { n pengetahuan dan } \\
\text { keterampilan }\end{array}$ & $\begin{array}{l}\text { Guru } \\
\text { mendemonstrasikan } \\
\text { keterampilan dengan } \\
\text { benar, atau menyajikan } \\
\text { informasi tahap demi } \\
\text { tahap }\end{array}$ \\
\hline $\begin{array}{l}\text { Fase 3 } \\
\text { Membimbing } \\
\text { pelatihan }\end{array}$ & $\begin{array}{l}\text { Guru merencanakan } \\
\text { dan memberikan } \\
\text { bimbingan awal }\end{array}$ \\
\hline $\begin{array}{l}\text { Fase 4 } \\
\text { Mengecek } \\
\text { pemahaman dan } \\
\text { memberikan } \\
\text { umpan balik }\end{array}$ & $\begin{array}{l}\text { Mengecek apakah } \\
\text { siswa telah berhasil } \\
\text { melakukan tugas } \\
\text { dengan baik. Memberi } \\
\text { umpan balik }\end{array}$ \\
\hline $\begin{array}{l}\text { kesempatan untuk } \\
\text { dan penerapan }\end{array}$ & $\begin{array}{l}\text { Guru mempersiapkan } \\
\text { kesempatan melakukan } \\
\text { pelatihan lanjutan, } \\
\text { dengan perhatian } \\
\text { khusus pada penerapan } \\
\text { kepada situasi lebih } \\
\text { kompleks dan } \\
\text { kehidupan sehari-hari }\end{array}$ \\
\hline
\end{tabular}

Berdasarkan permasalahan tersebut maka alternatif pendekatan pembelajaran yang tepat pada mata pelajaran bahasa Indonesia yaitu dengan strategi direct instruction. Direct instruction mengarah pada dunia akademis yaitu metode pengajar yang menggunakan materi yang terstruktur dan berkelanjutan. Pada strategi ini tujuan pada aktivitas pengajaran adalah tingkat pemahaman konsep pelajaran bagi siswa, alokasi waktu untuk instruksi cukup dan kontinue, isi materi berkembang, performance siswa dimonitor dan feedback pada siswa diberikansegera dan berorientasi akademis.

Berdasarkan uraian pada latar belakang masalah, maka dapat dirumuskan permasalahan sebagai berikut: "Apakah dengan menggunakan pembelajaran strategi pembelajaran langsung (direct instruction) meningkatkan hasil belajar bahasa Indonesia siswa kelas I SD Negeri 167644 kota Tebing Tinggi Tahun pelajaran 2013/2014?"

Tujuan dari penelitian ini adalah untuk meningkatkan hasil belajar Bahasa Indonesia siswa kelas I SD Negeri 167644 Tebing Tinggi tahun pembelajaran 2013/2014 melalui strategi direct instruction.

\section{METODE PENELITIAN}

Penelitian ini dilaksanakan di SD Negeri 167644 Tebing Tinggi. Penelitian ini dilaksanakan pada bulan Februari sampai dengan bulan April 2014 pada semester genap tahun ajaran 2013/2014. 
Subjek penelitian adalah siswa kelas I SD Negeri 167644 Tebing Tinggi dengan jumlah siswa sebanyak 33 orang dengan 15 orang laki-laki dan 18orang perempuan. Sumber data yang digunakan adalah peserta didik, informan, peristiwa yang terjadi selama kegaiatan belajar mengajar. Pada penelitian tindakan kelas data yang dikumpulkan dapat berbentuk kuantitatif maupun kualitatif. Data kuantitatif yang berupa nilai dianalisis dengan menggunakan analisis deskriptif komparatif yaitu membandingkan nilai tes kondisi awal, nilai tes setelah siklus I dan II yaitu nilai dari hasil ulangan harian siswa kelas I SD Negeri 167644 pada siklus I dan II.

Metode penelitian yang digunakan dalam penelitian ini adalah Classroom Action Research atau penelitian tindakan kelas. Penelitian Tindakan Kelas merupakan suatu bentuk penelitian yang bersifat reflektif dengan melakukan tindakan-tindakan tertentu agar dapat memperbaiki dan atau meningkatkan praktek-praktek pembelajaran di kelas secara lebih professional (Agung, 2010;3). Model penelitian tindakan kelas yang digunakan peneliti adalah sistem spiral refleksi diri yang dikembangkan oleh Kemmis dan Taggart yang dimulai dengan perencanaan, tindakan, pengamatan, dan refleksi. Masingmasing siklus terdiri dari dua kali pertemuan yaitu sebagai berikut;

\section{Perencanaan}

Tahapan ini berupa menyusun rancangan tindakan yang menjelaskan tentang apa, mengapa, kapan, di mana, oleh siapa, dan bagaimana tindakan tersebut akan dilakukan. Pada tahap siklus I yaitu membuat perencanaan dan program penelitian, yang nantinya menjadi pedoman melaksanakan penelitian ini, yaitu:

a. Menyusun silabus pada sikus I

b. Menyusun Rencana Pelaksanaan Pembelajaran (RPP) siklus I

c. Menyusun lembar observasi guru dan siswa

d. Menyusun lembar evaluasi siswa

\section{Pelaksanaan}

\section{Siklus I}

Guru melakukan pembelajaran di dalam kelas dengan menggunakan panduan perencanaan yang telah dibuat. Siklus I dilakukan pada tanggal 4 Maret 2014. Penerapan strategi direct instruction dilakukan dengan guru mempersiapkan siswa sebelum melakukan pembelajaran dan menyampaikan tujuan pembelajaran. Dalam pelaksanaan ini disusun sesuai tahap pelaksanaan model pembelajaran langsung sesuai dengan prosedur yang telah dirancang.

Kompetensi dasar yang dipelajari pada siklus ini adalah menulis kalimat sederhana yang didiktekan guru dengan huruf tegak bersambung. Pada saat kegiatan pembelajaran berlangsung guru sebagai peneliti dibantu oleh para observer lainnya untuk melakukan pengamatan, mendokumentasi kegiatan, selain itu peneliti bertindak sebagai fasilitator, motivator dan sekaligus sebagai pengamat. 


\section{Siklus II}

Guru melakukan pembelajaran di dalam kelas dengan menggunakan panduan perencanaan yang telah dibuat. Siklus II dilakukan pada tanggal 18 Maret 2014. Penerapan strategi direct instruction dilakukan dengan guru mempersiapkan siswa sebelum melakukan pembelajaran dan menyampaikan tujuan pembelajaran. Dalam pelaksanaan ini disusun sesuai tahap pelaksanaan model pembelajaran langsung sesuai dengan prosedur yang telah dirancang.

Kompetensi dasar yang dibahas pada siklus ini adalah mengulang deskripsi tentang benda-benda di sekitar. Pada Siklus kedua ini juga, suasana pembelajaran masing-masing kelompok di lingkungan sekolah dikondisikan agar tidak terlalu formal, maksudnya siswa bebas mengemukakan pendapatnya tentang materi ajar sesuai dengan kompetensi dasar yang ingin dicapai.

\section{Observasi/Pengamatan}

Pada tahap ini dilaksanakan proses observasi. Proses pembelajaran sesuai dengan langkah-langkah model pembelajaran langsung (direct instruction) melalui pembelajaran bahasa Indonesia. Memberi penilaian terhadap anak meliputi proses dan hasil pembelajaran yang dikumpulkan. Pengamatan dilakukan peneliti sendiri dan dibantu oleh pengamat dan mencatat proses penerapan teknik pengajaran kolaborasi.

\section{Refleksi}

Peneliti mengkaji, melihat dan mempertimbangkan hasil atau dampak dari tindakan yang dilakukan berdasarkan lembar pengamatan yang diisi oleh pengamat. Kegiatan pada tahap refleksi meliputi kegiatan menganalisis, memahami dan membuat kesimpulan berdasarkan hasil observasi setiap siklus, menemukan kelebihan dan kelemahan tindakan perbaikan pembelajaran. Hasil analisis data yang dilaksanakan pada tahap ini akan dipergunakan untuk menemukan kelebihan dan kelemahan diri dalam merancang dan melakukan tindakan sebagai acuan.

Metode pengumpulan data penelitian ini adalah tertulis dan observasi. Penelitian ini dikatakan berhasil apabila siswa telah memperoleh nilai ketuntasan secara klasikal minimal $85 \%$ dari jumlah siswa dengan rumus sebagai berikut :

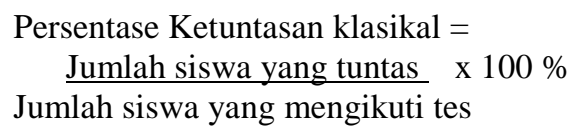

\section{HASIL PENLITIAN DAN PEMBAHASAN}

Hasil penelitian tindakan kelas yang peneliti paparkan ini berupa hasil tes dan non tes yang berasal dari hasil prasiklus, siklus I dan siklus II. Hasil prasiklus berupa kondisi awal siswa sebelum dilakukan penelitian yaitu hasil pembelajaran Bahasa Indonesia yang belum menggunakan model pembelajaran Direct Instruction. Sedangkan siklus I dan siklus II merupakan hasil pembelajaran Bahasa 
Indonesia melalui model pembelajaran Direct Instruction. Pada kondisi awal (prasiklus) diperoleh ketuntasan belajar siswa secara klasikal yaitu 23 orang $(69,69 \%)$ siswa yang tuntas. Angka ini berarti masih kurang dari kategori tuntas. Siswa belum dapat menguasai materi Bahasa Indonesia sehingga hasil belajar siswa rendah maka dari itu dilanjutkan ke siklus I.

Siklus I dilaksanakan 2 kali pertemuan yaitu 1 kali pertemuan untuk pelaksanaan tindakan dan 1 kali pertemuan untuk melaksanakan penilaian terhadap perkembangan hasil belajar siswa. Hasil penelitian tindakan kelas menunjukkan bahwa pengamatan yang dilakukan oleh mitra kolaborasi dan peneliti pada aktivitas guru dan siswa melalui penerapan strategi direct instruction pada mata pelajaran Bahasa Indonesia dapat dilihat pada Tabel berikut :

\section{Tabel Peningkatan Hasil Belajar} Siswa Pra Siklus, Siklus I dan II

\begin{tabular}{|c|c|c|c|}
\hline \multicolumn{2}{|c|}{ Peningkatan Hasil Belajar } & \multirow{2}{*}{ Ket } \\
\cline { 1 - 3 } $\begin{array}{c}\text { Pra } \\
\text { Siklus }\end{array}$ & $\begin{array}{c}\text { Siklus } \\
\text { I }\end{array}$ & $\begin{array}{c}\text { Siklus } \\
\text { II }\end{array}$ & \\
\hline 23 & 26 & 30 & $\begin{array}{c}\text { Jumlah Siswa } \\
\text { Lulus }\end{array}$ \\
\hline 69,69 & 78,78 & 90,90 & $\begin{array}{c}\text { Persentase } \\
\text { Ketuntasan } \\
\text { Belajar (\%) }\end{array}$ \\
\hline
\end{tabular}

Berdasarkan pengamatan peneliti dari tindakan pra siklus, siklus I dan II terjadi peningkatan hasil belajar pada jumlah siswa dan persen ketuntasan belajar secara klasikal. Persentase ketuntasan belajar dapat ditingkatkan setelah diberikan tindakan pada siklus I, yaitu meningkat menjadi $78,78 \%$ dari $69,69 \%$ sebelum dilakukannya siklus I. Berarti terjadi peningkatan sebesar 9,09\%, dimana data pengamatan dilakukan dengan mencermati aktivitas siswa selama pelajaran berlangsung.

Data hasil belajar siswa dikumpulkan dengan metode tes. Peneliti memberikan tes akhir siklus pada pertemuan kedua. Tes yang diberiksn berupa soal-soal isian yaitu 10 soal objektif dan uraian. Setelah diadakan tes akhir sebagai evaluasi akhir siklus I, maka diperoleh rata-rata nilai hasil belajar Bahasa Indonesia pada siklus I adalah 64,25. Dari 33 orang siswa yang mengikuti ujian pada pelajaran bahasa Indonesia hanya 26 orang siswa yang tuntas. Selanjutnya jika dipersentasekan ketuntasan belajar siswa secara klasikal adalah 78,78\% atau siswa yang memperoleh nilai $\geq 65$ hanya sebesar 78,78\%. Berdasarkan data tersebut, maka dapat disimpulkan bahwa rata-rata nilai hasil belajar siswa secara klasikal pada siklus I sebesar 64,25 dengan persentase 78,78\%, menggambarkan bahwa hasil belajar siswa masih rendah yaitu dibawah KKM $(\geq 65)$ dan dibawah ketuntasan belajar ( $\geq 85 \%)$.

Pengamatan terhadap kompetensi belajar siswa pada siklus I dengan tindakan melalui model pembelajaran langsung (direct instruction) berbantuan modul yang digunakan guru pada pembelajaran Bahasa Indonesia memperoleh pancapaian kompetensi siswa, hal ini ditunjukkan pada sajian data pada tabel 2 bahwa 78,78\% siswa sudah memenuhi kriteria ketuntasan belajar 
secara klasikal. Namun angka tersebut belum cukup untuk mencapai ketuntasan belajar secara klasikal. Meskipun begitu ada peningkatan hasil belajar siswa dari siklus sebelum dilakukan siklus I.

Kurangnya hasil belajar ini terjadi karena siswa tersebut tingkat pemahamannya lebih rendah dibanding siswa yang lain dan siswa masih enggan untuk bertanya pada guru saat mengalami kesulitan, sehingga guru harus melakukan perbaikan agar semua siswa dapat memahami materi yang disampaikan oleh guru. Hasil tersebut menggambarkan perlu adanyasuatu tahapan selanjutnya untuk memperbaiki hasil belajar agar target yang diharapkan dapat tercapai. Meskipun demikian, terjadi peingkatan hasil belajar siswa dari pra siklus ke siklus I walaupun hasilnya belum sesuai dengan indikator keberhasilan. Hal ini membuktikan bahwa dengan penerapan metode direct instruction dapat meningkatkan hasil belajar siswa kelas I SD 167644 Tebing Tinggi.

Strategi pembelajaran langsung, selain efektif untuk digunakan oleh siswa untuk menguasai suatu pengetahuan deklaratif dan pengetahuan prosedural maka juga efektif digunakan untuk mengembangkan keterampilan belajar siswa. Hal ini sejalan dengan pendapat Trianto (2009: 41), pengajaran langsung adalah suatu model pengajaran yang bersifat teacher center. Model pengajaran langsung adalah salah satu pendekatan mengajar yang dirancang khusus untuk menunjang proses belajar siswa yang berkaitan dengan pengetahuan deklaratif dan pengetahuan prosedur yang terstruktur dengan baik yang dapat diajarkan dengan pola kegiatan yang bertahap, selangkah demi selangkah.

Pada Tabel 2, strategi pembelajaran direct instruction pada siklus II diperoleh nilai rata-rata ulangan harian siswa adalah 68,48 dan ketuntasan belajar mencapai 90,90\% atau ada 30 siswa dari 33 siswa sudah tuntas belajar. Hasil tersebut menunjukkan bahwa pada siklus kedua secara klasikal sudah tuntas belajar, karena siswa yang memperoleh nilai $\geq$ 65 sebesar 90,90\% sudah memenuhi kriteria dari persentase ketuntasan yang dikehendaki yaitu sebesar 85\%. Oleh karena itu dilanjutkan penelitian siklus kedua untuk meningkatkan hasil belajar siswa.

Siklus II dilaksanakan 2 kali pertemuan yaitu 1 kali pertemuan untuk pelaksanaan tindakan dan 1 kali pertemuan untuk melaksanakan penilaian terhadap perkembangan hasil belajar siswa yang berjumlah 33 anak. Pelaksanaan tindakan pada siklus II dilaksanakan berdasarkan Rencana Kegiatan Harian (RKH) yang sudah disiapkan sebelumnya.

Pada siklus II, siswa sudah memahami konsep materi dengan baik. Pembelajaran yang dilaksanakan telah mampu meningkatkan hasil belajar siswa dan telah mencapai kriteria ketuntasan belajar yang diharapkan. Dengan penerapan strategi direct instruction dapat meningkatkan penguasaan materi siswa untuk mata pelajaran. Hal ini terlihat dari perbandingan hasil belajar siswa sebelum pemberian tindakan dengan setelah pemberian tindakan pada siklus 
I dan siklus II. Peningkatan yang baik dicapai setelah diberikannya tindakan dengan penerapan pembelajaran direct instruction dari siklus I ke siklus II sebesar 15,15\%. Dimana dari hasil tes yang diberikan persentase ketuntasan siswa mencapai $90,90 \%$ dengan ratarata nilai 68,48 . Secara klasikal siklus II dinyatakan telah memenuhi kriteria penilaian.

Melalui perbaikan proses pembelajaran pada pelaksanaan siklus I, maka pelaksanaan proses pembelajaran pada siklus II telah nampak adanya suatu peningkatan proses pembelajaran dari hasil belajar siswa. Adapun beberapa temuan yang dapat diperoleh selama tindakan pelaksanaan siklus II, yaitu kondisi dan situasi belajar siswa pada setiap pertemuan menunjukkan situasi belajar yang lebih kondusif, bersemangat, percaya diri, jika dibandingkan dengan pertemuan pertemuan sebelumnya pada waktu siklus I.

Pada siklus II, siswa sudah terbiasa dengan penerapan model pembelajaran langsung menuntut aktivitas tinggi dan mau berkolaborasi dengan guru dalam proses pembelajaran. Siswa tampak sudah mampu lebih mandiri setelah mendapat penjelasan dan contoh yang diberikan dari guru dan bahkan siswa yang lebih cepat menerima pelajaran mampu membantu temannya yang lain yang belum bisa menjawab pertanyaan guru dengan benar.

Penerapan strategi direct instruction dapat memberikan manfaat yang positif kepada siswa dan juga guru. Peningkatan mutu pembelajaran yang tercermin dari hasil belajar siswa dapat dicapai dengan penerapan model pembelajaran ini. Karena strategi ini menghendaki guru memberikan informasi latar belakang, mendemonstrasikan keterampilan yang sedang diajarkan, dan kemudian menyediakan waktu bagi peserta didik untuk latihan keterampilan tersebut dan menerima umpan balik tentang bagaimana dan apa yang peserta didik lakukan.

Pendapat tersebut sejalan dengan Amri dan Ahmadi, (2010: 39) bahwa model pembelajaran langsung (Direct Instruction) merupakan salah satu model pengajaran yang dirancang khusus untuk mengembangkan belajar siswa tentang pengetahuan prosedural dan pengetahuan deklaratif yang terstruktur dengan baik dan dapat dipelajari selangkah demi selangkah.

Selain itu peran guru juga mempengaruhi hasil belajar siswa. Guru harus mampu menciptakan suatu lingkungan belajar yang kondusif dan memahami kesulitan yang dihadapi siswa ketika pembelajaran berlangsung. Guru harus menghindari penyajian informasi dalam bentuk ceramah karena hal ini akan mengakibatkan kurangnya partisipasi siswa dalam kegiatan pembelajaran untuk memenuhi salah satu karakteristik model yang diharapkan siswa menjadi aktif dalam mencari dan mengolah sendiri informasi.

Pada siklus II guru berusaha untuk memperbaiki kekurangan dalam proses belajar mengajar melalui model pembelajaran langsung berbantuan modul yang terjadi pada siklus I dengan 
berlatih dan membiasakan untuk memberikan materi. Guru lebih banyak melakukan interaksi dengan memberikan bimbingan dan melakukan pendekatan terhadap siswa dan materi pembelajaran bahasa Indonesia yang disampaikan lebih terstruktur sehingga siswa lebih mudah dalam menerima materi yang disampaikan oleh guru.

Dari hasil tes ini dapat dilihat bahwa hasil belajar dengan menggunakan strategi pembelajaran direct instruction telah mampu meningkatkan hasil belajar siswa mengenai materi pelajaran bahasa Indonesia sesuai dengan indikator yang telah ditentukan sehingga tidak perlu lagi dilanjutkan pada siklus berikutnya dan dikatakan berhasil.

Peneliti bersama teman sejawat dan guru menyimpulkan bahwa pembelajaran mata pelajaran bahasa Indonesia strategi pembelajaran langsung (direct instruction) dapat meningkatkan kompetensi dan hasil belajar siswa. Dengan adanya pencapaian hasil kompetensi pada siklus II, sesuai dengan kriteria keberhasilan tindakan yang ingin dicapai yaitu, pencapaian ini sesuai dengan kriteria keberhasilan tindakan yang ingin dicapai yaitu apabila minimal $85 \%$ siwa tuntas (mencapai KKM) dengan pencapaian hasil kompetensi lebih baik dari yang sebelumnya.

\section{KESIMPULAN}

Dari hasil temuan penelitian tentang hasil belajar siswa dengan strategi pembelajaran langsung (direct instruction) di kelas I SD Negeri 167644 Tebing Tinggi tahun pelajaran
2013/2014 berdampak positif dalam meningkatkan hasil belajar siswa. Hasil belajar siswa pada pembelajaran Bahasa Indonesia meningkat dari kondisi prasikus, siklus I dan siklus II. Hal tersebut dapat dilihat dari peningkatan persentase ketuntasan belajar siswa pada prasiklus $(69,69 \%)$, siklus I $(78,78$ $\%)$, siklus II (90,90\%).

Atas dasar simpulan dan implikasi hasil penelitian tindakan kelas di atas, penulis memberikan saran-saran sebagai berikut :

1. Bagi Sekolah

Sekolah seyogyanya selalu memperhatikan kualitas pendidikan dengan membiasakan menggunakan model pembelajaran yang variatif, kreatif dan inovatif.

2. Bagi Guru

Jika di dalam penelitian terdapat prosedur - prosedur yang harus dilakukan subjek penelitian, guru supaya benar benar memberikan pengertian kepada subjek penelitian agar tidak terjadi kesalahan dalam melaksanakan penelitian.

3. Bagi Siswa

Siswa diharapkan untuk turut berperan aktif dalam proses pembelajaran di kelas serta menumbuhkan rasa ingin tahu yang lebih karena motivasi siswa yang tinggi dalam pembelajaran sangat diperlukan agar pembelajaran berhasil.

\section{DAFTAR RUJUKAN}

Agung. 2010. Penelitian Tindakan Kelas. Singaraja: Universitas Pendidikan Ganesha.

Amri, S, dkk. 2010. Proses Pembelajaran Kreatif dan 
Inofatif Dalam Kelas. Jakarta: Prestasi Pustaka Publisher.

Arends, Richardl. 1997. Classroom Instructional Management. New York: The McGraw-Hill Company.

Harjani. 2010. Upaya Meningkatkan Prestasi Belajar Siswa Dengan Penerapan Model Pembelajaran Direct Instruction Pada Mata Pelajaran Akuntansi Kelas X Akuntansi 1 SMK Negeri 1 Sukoharjo Tahun Ajaran 2009/2010. Skripsi. Surakarta: Universitas Sebelas Maret.

Krisnawati, Md., N.W. Arini, M.

Suarjana. 2013. Penerapan Pendekatan (PAKEM) Untuk Meningkatkan Aktivitas dan Hasil Belajar Bahasa Indonesia Siswa Kelas IV SD No.2 Pemaron. Jurnal. Universitas Pendidikan Ganesha. Singaraja.

Trianto. 2009. Mendesain Model Pembelajaran InovatifProgresif. Jakarta: Kencana Prenada Media Grup. 